Cornell Law Library

Scholarship@Cornell Law: A Digital Repository

Cornell Law Faculty Publications

Faculty Scholarship

1995

\title{
The View from the International Plane: Perspective and Scale in the Architecture of Colonial International Law
}

Annelise Riles

Cornell Law School, ar254@cornell.edu

Follow this and additional works at: http://scholarship.law.cornell.edu/facpub

Part of the International Law Commons, and the Legal History, Theory and Process Commons

\section{Recommended Citation}

Riles, Annelise, "The View from the International Plane: Perspective and Scale in the Architecture of Colonial International Law" (1995). Cornell Law Faculty Publications. Paper 1072.

http://scholarship.law.cornell.edu/facpub/1072

This Article is brought to you for free and open access by the Faculty Scholarship at Scholarship@Cornell Law: A Digital Repository. It has been accepted for inclusion in Cornell Law Faculty Publications by an authorized administrator of Scholarship@Cornell Law: A Digital Repository. For more information, please contact jmp8@cornell.edu. 
Law and Critique Vol.VI no.1 [1995]

\author{
THE VIEW FROM THE INTERNATIONAL PLANE: \\ PERSPECTIVE AND SCALE IN THE ARCHITECTURE \\ OF COLONIAL INTERNATIONAL LAW
}

by

ANNELISE RILES

When 1 first became acquainted with the country the natives thought their country the biggest in the world. When new-comers differed from them on this point, they roundly called them liars. That was fifty years ago, and in the meantime the slow but steady pressure of education afforded by the Mission Schools has taught them otherwise. ${ }^{1}$

The countryside, the immense geographic countryside, seems to be a deserted body whose expanse and dimensions appear arbitrary (and which is boring to cross even if one leaves the main highways), as soon as all events are epitomized in the towns, themselves undergoing reduction to a few miniaturized highlights. ${ }^{2}$

The representational gaze has by now become an ubiquitous motif of scholarship about colonial law and administration. Following the insights of Michel Foucault and recent trends in feminist theory, numerous writers have turned their attention to the perspective that often animated colonial rule. $^{3}$ In the pages below, I wish to contribute to this line of inquiry by

- Department of Social Anthropology. University of Cambridge, Free School Lane. Cambridge CB2 3RF. England. I owe special thanks to Peter Fitzpatrick. David Kennedy. Angelia Means. Adam Reed, and Marilyn Strathern for conversation and detailed comments that substantially shaped the direction of this prece 1 am also indebted for useful criticism to the Law and Social Theory seminar group at the University of Kent at Canterbury and to the "Anthropological Methods in the Realm of the International" discussion at the 1994 Law and Society Annual Meeting, as well as to the Ford Foundation for financial support

1 A.B. Brewster, The Hill Tribes of Fiji 38 (New York: Johnson Reprint Co., 1967 [1922|).

2 J. Baudrillard, "The Ecstasy of Communication", in H. Foster, ed., The AntiAesthetic: Essays on Postmodern Culture (Seattle: Bay Press. 1983). 129.

3 See. e.g. P. Rabinow. French Modern (Cambridge, Mass.: The M.I.T. Press, 1989) (interpretıng French urban planning policies in colonial Algeria as "an 


\section{Law and Critique Vol.VI no.1 [1995]}

considering the sense of dimension or scale that characterized the interna tional legal project of the colonial era. ${ }^{4}$ An implicit notion of scale - of the difference between large and small - is a crucial foundation for the effect of perspective, colonial or otherwise. As such, the turn in contemporary criticism toward the study of colonial perspective might also be a study of colonial notions of scale.

For the late nineteenth century international lawyer, too, scale was a fundamental, if unremarked, aspect of the disciplinary project. The international lawyer's task, 1 argue, was to transform "local" disputes into mat ters of global importance, into stepping stones in the trajectory toward global peace. What differentiated the local and the global for the late nineteenth century international lawyer was precisely a notion of size or scale. What was international and global, in other words, was understood as larger than what was local or national. From the vantage point of the international lawyer's globalizing gaze, distant events "on the ground" were "spotted" as international issues, and the adjudication of international disputes was understood to take place on an "international plane" different in scale from these events themselves. This globalizing perspective, I believe, was central in giving effect to the discipline's normative project of cosmopolitanism. ${ }^{3}$

urban parallel to Bentham's Panoptcon "), F. Cooper, and A.L. Stoler, "Tensions of Empire. Colonial Control and Visions of Rule". American Ethnolagist 16 (1989).609. T. Mitchell, "Orientalism and the Exhibitionary Order." in N. Dirks. ed.. Colonialism and Culture Ann Arbor: University of Michigan Press, 1992). 289-317. So pervasive is the theme of colonial perspective that one recent work. again citing Foucault's image of the Panopticon, identifies the colonial interest in surveillance as one of twelve basic rhetorical modes which are said to form a repertoire for colonial discourse. D. Spurr. The Rhetoric of Empire (Durham. N.C.: Duke University Press, 1993)

4 For further elaboration of international law's implication in colonial expansion. see Antony Anghie. "The Heart of My Home': Colonialism. Environmental Damage, and the Nauru Case". Harvard International Lau Journal $34 / 2$ (1993), 445.506

5 In this sense, the international lawyer's globalizing view mirrors the powerful globalism of a vanety of thetorics now critiqued by contemporary writers. Elspeth Probyn speaks for many critics, for example, when she notes "(t) ways in which women's practices and experiences have been historically dismissed as local" and the way in which the epistemology of location works to "fix the subaltern outside the sanctified boundaries of knowledge; determining the knowledge of the subaltern as peripheral and inconsequential": E. Probyn, "Travels in the Postmodern: Making Sense of the Local". in L.J. Nicholson, ed., 
What does it mean, then, for "local" events to become international by becoming "larger" as they become global? It is difficult to talk about this notion of scale in international legal culture because it is an implicit, nat uralized starting point, a base taken for granted by all sides upon which the more important, contested issues are played out. Perbaps it is this ubiquitous notion of scale that makes normative debate possible in the first place.

My aim in raising this question addresses itself as much to the state of contemporary critical theory as it does to nineteenth century international law. Notions of scale, perspective and place surface everywhere in contemporary theory. If we take international law, as nineteenth and twentieth century international lawyers have, as an institutional elabora tion of modern and liberal philosophical themes, a consideration of how these themes operate for international lawyers may hold important implications for the way the same notions are deployed in "critiques" of modernist thought.

In order to consider this question, however, it becomes necessary to manufacture a rhetorical situation that will allow us to apprehend our taken-for-granted notion of scale. I suggest, therefore, that we treat a routine move of international legal strategy, chosen from one ordinary controversy of the coional period, as if it presented a puzzle for us. Why do the lawyers in the case below apprehend the scale of international legal conversation as they do. I propose to ask. In other words, I propose to set aside for the moment the more commonly debated question of why either side would embrace or reject international law as a vehicle for their cause, or how substantive and procedural doctrine could be manipulated to show grounds for international argument. Rather, the question I wish to address is not why international legal conversation should take place but why that conversation should be defined by a sense of difference in scale. ${ }^{6}$

Feminism/Postmodernism (New York: Routledge, 1990), 178.

6 As noted at the outset. It is difficult to separate analytically the implicit perspectival manoeuvres of the international lawyers from the explicit doctrinal conversation precisely because a shared sense of perspective serves as founda tion for normative debate. Yet although one can identify parallels between ar. guments for or aganst the admission of a claim under international law, for example. and implications of a greater or lesser sense of distance between global and local. these are not identical manoeuvres, and perspective and argument do not move together. As we will see, an appeal to either the admission or rejection of a claim can be made from the vantagepoint of a global plane distant from local events, or alternatively can attempt to refuse the perspecti. 
The case dates to late nineteenth century colonial Fiji. The claimants were Americans whose lands in Fiji had been confiscated by the Land Claims Commission of Fiji's first Governor, Sir Arthur Gordon, who arrived in the British colony in $1875 .^{7}$ An amateur ethnologist, Gordon envisaged his primary task to be the preservation of native culture from the harm of civilization. ${ }^{8}$ The Commission's task, therefore, was to investigate every European title to ensure that the property had been alienated according to what Gordon lovingly called "ancient custom". 9 Among those denied title was this group of Americans who shared none of Gordon's nostalgia for cultural difference.

The conflict catapulted to the international plane when, on July 1 , 1887 , after ten years of frustration at pressing the issue through administrative appeal, the claimants wrote to the President of the United States, Grover Cleveland. ${ }^{10}$ Cleverly spotting an issue of international law, Cleveland forwarded the letter to the State Department, " which appointed a special agent to travel to Fiji to investigate the claims. ${ }^{12}$ Over the next thirty-five years, the affair languished on the desks of British Foreign Office and State Department lawyers who exchanged endless diplomatic correspondence on the subject. ${ }^{13}$ By 1896 alone, the volume of State Department documents relating to one claimant's case amounted

val distance of the cosmopolitan from the everyday.

7 See "Report of Mssrs. Williamson and Carew, Land Commissioners, on 'Emuri', Together with the Testimony and Proceedings on the Hearing Before them". American and British Claims Arbitration, Fiji Land Claims of George Rodney Burt, Benson Robert Henry, John B. Williams, Isaac M. Brower, Memorial of the United States in Support of the Claims (1914). Exhibit 26, at 199-204 Thereinafter U.S. Memoral!

8 See J.D. Legge. Britain in Fij, 1858-1880 (London: Macmillan, 1958).

9 "Report of the Lands Commission", quoted in Pecuntary Claims Arbitration, George Rodney Burt. Answer of His Majesty's Government. Annex 4, at 46 (July 9, 1923) (hereinafter Britush Memorial, Rodney Burt)

10 See Mis. Doc. No. 173. 51 st Cong., 1st Sess. (1890).

11 See U.S. Memortal, supra D.7, at 15.

12 See ibid. at 16-17. The special agent, George H. Scidmore, was appointed in 1891 and filed his report with the Dept. of State on July 3, 1893 after a year of research in Fiji. See "Report of Mr. George H. Scidmore, special agent of the Department of State to investigate claims of American citizens to lands in Fiji". S. Doc. No. 126. 54 th Cong.. 1st Sess. 2 (1896).

13 See generally, correspondence reprinted in S. Doc. No.140, 56th Cong.. 2d Sess. (1901). 
to 1,717 pages of written material, 163 pages of printed material, and another 852 pages of British government documents. ${ }^{14}$

This controversy now found itself caught in the trajectory of a new narrative. The late nineteenth century saw a flurry of activity aimed at the expansion of the rule of law in the international sphere. Theorists during this classical period of international legal doctrine treated international law as a project of elaborating the rules for a new and higher order of society, ${ }^{15}$ a society of states. ${ }^{16}$ The first steps toward true world government would be to convince the "civilized states" to submit disputes to voluntary arbitration in hopes that this process eventually would lead to the establishment of a binding world court. ${ }^{17}$ As enthusiastic supporters of the judicial settlement of international disputes, the United States and Britain established in 1910 a Pecuniary Claims Arbitration procedure ${ }^{18}$ under the auspices of the Hague Convention of 1907. Among the outstanding claims between the two countries listed in a schedule appended to the agreement were the Fiji claims. The propriety of Gordon's colonial policies had now become "Class I - claims based on an alleged denial in whole or in part of real property rights," grouped together with events in New Zealand, the Malay Peninsula, South Africa, Quebec, New

14 See Message from the President of the United States, SD OC. NO 126, 54th Cong.. ist Sess. 2 (1896)

15 The views of the publicist Thomas Lawrence exemplified the enthusiasm of the time:

I have indicated my belief that the period of rapid development through which we are now passing may end, of those who stand for righteousness among the nations are at once sane in their aims and earnest in their endeav ours, in the establistiment of an organized international society, with legislative. executive, and judicial organs. Were this once done. war would in time become as abnormal and infrequent as rebellion.

T.J. Lawrence. The Principles of International Law (Boston: D.C. Heath \& Co., 1910. 4th ed.). v.

16 See W.E. Hall. International Lau (Oxford Clarendon Press. 1880), 5.

17 During this period. for example. the American Society for the Judicial Settlement of International Disputes was founded for the "promotion of the project to establish a judicial tribunal which will do for the civilized world what the ordinary courts of justice do for the individual and to encourage recourse to it when established": "The American Society for Judicial Settlement of International Disputes". Judicial Settlement of International Disputes 1910.12 (1910), 25

18 See Agreement Between Great Britain and the United States for the Settlement of Pecuniary Claims. Aug. 18, 1910,211 CTS 408. 


\section{Law and Critique Vol.VI no.1 [1995]}

Mexico, New York. ${ }^{19}$

The puzzle 1 wish to unravel concerns correspondence between the British and American lawyers at two junctures. First, during negotiations between the parties over whether to submit the dispute to arbitration, the Americans write to the British Foreign Office, and present a classic international legal perspective on the events. They take note, first. of the deed of cession, and second, of the lack of the kind of judicial procedures on the part of the Land Claims Commission that they claim are mandated by in ternational law, ${ }^{\infty}$ and they conclude by suggesting the appointment of a mixed commission to resolve the claims. ${ }^{21}$ At this point, they have presented the events from a perspective that looks as effortlessly on a conflict in Fiji as on a series of facts located in any other part of the world, and that finds in the Fijian case a matter of interest to the cosmopolitan centre.

The conflict now appears to be a conversation between sovereigns in the cosmopolis. Yet the British respond in a quite different way. There simply is no issue of international law to discuss, they contend, because the Land Claims Commission was fully impartial. ${ }^{22}$ A focus that cuts to a fact, a change to a different level of analysis, wrecks the architecture that sustains an international conversation.

Later in the negotiation process, in response to the U.S. State Department's detailed arguments about the illegality of British actions, the British drop to the local level with a surprise challenge to the identity of the American claimants. "Lord Salisbury may be aware." the colonial office writes to the foreign office, "that among the American claims ad. vanced in Fiji some, it is understood, were put forward by ... the American Consul on behalf of the bastard offspring of Native women who. of course, are not American citizens ..." ${ }^{23}$ Without citizenship. there can be no contest, for access to international law must depend on the trans formation of rightful citizens' claims into those of the representative state. The surprise proves effective: on this basis, the Department of State reduces

19 Ibid.

20 Letter from E.J. Phelps to the Marquis of Salisbury. Head of the Foreign Office, Nov. 12.1887.

21 loid

22 Letter from J. Pauncefote to Colonial Office, appending a draft letter to the United States Minister. December 28, 1887.

23 Letter from John Bramston, Colonial Office, to Lord Salisbury. Foreign Office, December 9. 1887 (Collection of the National Archives of Fiji). 
the number of claims from 53 to only $10 .^{24}$

We might note at the outset the notion of scale at work here. The tribunal's schedule of claims assumes a position equidistant from New York or New Zealand. The conversation between British and American lawyers, for their part, is meaningful because these lawyers are understood as near to one another. Fiji, in contrast, is distant, and small for both parties. What contributed, then, to this sense of distance between an "international plane" and national activity? ${ }^{25}$ One central element was the way international lawyers treated certain events which at "close up" might have loomed large, as receding from view. Culture and race, for example, become explicitly distant subjects, understood in the metaphor of territory, and receded into the background of a cosmopolitan conversation like fragments of context for a foregrounded text. The character of Fijian culture now appears as a memorandum of evidence in the appendix to the British memorial ${ }^{26}$ behind other foregrounded concerns. The crucial issue, the British argue, is not the factual question of the nature of Fijian culture but the legal question of how to handle such custom:

|Alll the authorities are in agreement that until a comparatively short time before the cession the idea of such alienation was entirely unknown to the natives of Fiji. and that it was only by a gradual process of education that the character of such a transaction became understood at all

The point upon which a divergence of opinion may be detected is the question whether such altenation, being unknown as part of ancient custom, could ever become "legal ${ }^{27}$

The topic of culture is by no means "effaced" from the conversation because it is backgrounded, however. On the contrary, the sense of dimension is maintained precisely by the understanding that if one were to look closer, if one were to alter the scale, one would find it. It is the experience

24 See Letter from John Sherman. U.S. Dept of State. to John Hay, American Embassy. London (November 16. 1897) (printed in S. DOC. NO. 140. 56th Cong., 2d Sess 10119011)

25 One of the characteristics of the sense of scale and perspective I consider below is that it never becomes the subject of explicit conversation. This creates a problem for this piece. for the lack of nicely worded quotations in the documents renders it difficult to communicate in a very short number of words the Bense of scale that emerges from them. I have settled for presenting my conclusions about this perspective in essay form in hopes that sceptical readers will look for more detailed evidence in the wider project of which this is a part.

26 Britısh Memorial. Rodney Burt, supro n.9. Annex 4.

27 loud. Annex 4, at 41 . 


\section{Law and Critique Vol.VI no.1 [1995]}

of effecting this change in scale, moreover, the transformation of perspective that relegates culture to the appendix, that makes the distance of $\mathrm{di}$ mension real.

Plucked into the global arena by lawyers who "spot" legal issues, facts become building blocks of law, issues of legal significance. The friendship between Gordon and the members of the Land Claims Commission becomes a matter of inadequate procedure, for example. The expectations of Europeans and Americans about access to the spoils of colonialism become "land", and land becomes an element and fact of a new global arena. Certain elements of local scale are fished out - land, a deed of cession the British once enticed a Fijian chief to sign, the personal relations between members of the Land Claims Commission - so that it is not the entire landscape that is viewed from a distance, therefore. This local knowledge can be divorced from any particular argument "on the ground" to become simply phrases or appendices so that when one focuses in again on local scale, when one turns to the appendix of the memoranda, for example, these facts now loom large against other elements of local context. It is as though this local arena itself already contains the difference of scale that separates global and local. Nevertheless, what relates the global arena in perspectival terms to a local realm below is the feeling that behind such phrases as "land" and "cession" lie other phrases, other conflicts, other facts, and other perspectives. Every lawyer knows that on close examination, law dissolves into fact.

This sense of scale is elaborated much more through practice than through debate. The conversation of thirty-five years between British and American diplomats is an exchange of hundreds of short letters marked by their strict adherence to diplomatic form which speak far more frequently of the relationship among diplomats than they do of distant events in Fiji.

A typical letter reads: : $^{\text {n}}$

Foreign Office. March 18. 1897

SIR: I have had the honour to receive Mr. Bayard's note of the 8 th in stant. respecting the land clatms of the United States citizens in the Fiji lslands, and I have not failed to communicate a copy to Her Majesty's secretary of state for the colonies

I have, etc.

(For the Marquess of Salisbury:)

F.H. VILLIERS

28 Letter from F.H. Villiers. British Foreign Office. to Mr. Carter, American Embassy. (March 18. 1897) (reprinted in Claims of B.R. Henry and Others, SD $\propto$. NO 140. 56th Cong.. $2 d$ Sess. 5 (1901)). 
Yet who, we might ask, is F.H. Villiers? It is from his vantage point that the national environment and the details of the dispute look small and distant. And yet a global perspective must, by definition, overcome the subjectivity of any particular viewer. The metaphorical relationship between the society of states and a society of individuals that creates a distance of scale between persons and states $^{29}$ mandates that the individual and state are not literally identical. The international lawyer cannot occupy both positions at once. If he is a global viewer, he is not a local one.

The international lawyer, then, transforms himself into something greater and more universal than the subjectivity he shares with Gordon, the American claimants, or the Fijians whose lands have been alienated, ${ }^{30}$ just as the claims themselves must be transformed from those of persons into those of states. The lawyer becomes the state's representative, ${ }^{31}$ and even communicates with the state as entities of the same scale: in countless letters, the lawyer notes that "I am instructed by my Government to represent to Her Majesty's Government ..." ${ }^{32}$ And this transformation emphasizes the distance between the local and global, for in order to get from one to another, a change must take place, a work must be done. ${ }^{33}$ The lawyer, then, is located in space - in the space of the

29 See. e.g. Lawrence. Essays on Some Disputed Questions in Modern International Law (Cambridge: Deighton. Bell and Co., 1884), 57:

The lawyers on the whole regard Sovereignty as the Sovereignty exercised by individuals, and the result was extremely important to international law. for the assumed individuality of sovereigns enabled its founders to regard states as moral beings bound by moral rules.

30 The British lawyers act out this subjectivity, this shared sense of scale with the persons "on the ground", for example, as they correspond with and request advice from Gordon's successors in the Fijian colonial administration. See, e.g.. letter from J.B. Thurston to Lord Knutsford, Dec. 21, 1888 (Collection of the National Archives of Fiji)

31 The affinity between person and state. and the transformation it engenders, is the subject of much discussion by the publicists of the time. For example, William Hall writes that "States have a moral nature identical with that of in. dividuals, and that with respect to one another they are in the same relation as that in which in dividuals stand to each other who are subject to law": W. E. Hall. International Lau (Oxford: Clarendon Press, 1880), 13.

32 See, e.g.. Letter from E.J. Phelps to the Marquis of Salisbury. Head of the Foreign Office. Nov, 12, 1887.

33 "Probably it is best to say with Oppenheim that persons. like territory, are objects of International Law, and reserve the term subjects for those artificial 


\section{Law and Critique Vol.VI no.1 [1995]}

international plane and in the space he understands himself to occupy in the locality of daily life - and yet looks down from a vantage point that is greater than any particular space and captures in its gaze all space. And what is important is that contrary to the very notion of a difference between the state and the individual, and between the global and the local that animates the project of international law, the diplomat or lawyer understands himself to stand in both vantage points at once.

The observations above make evident, I think, that this difference of scale between an international plane and local events carries with it a notion of perspective. Perspective, of course, itself is both scale or dimension and the particularity of a point of view. Both notions work together here: for the international lawyer, to be situated "above," and to loom larger than local events was also to view the world below and to understand his view as a unique, particular vantage point. The unique aspect of this global perspective that made of the world a subject of viewing, however, was precisely the fact that it was a perspective from no point in particular. One finds in these debates a hope for world order through reason effectu ated in this detached view from above. ${ }^{34}$

Yet if it is a view from nowhere, the global perspective is also a view from an international plane. The global is both a way of looking that eclipses all others, and a space or place. The nation is a way of imagining identity that grafts itself onto a notion of territory. The local, as "location", is also an ideology. The cosmopolis is a utopian space as well as a set of scientific and moral values, ${ }^{35}$ and the international lawyer's

persons who are either sovereign states. or communities closely akin to them through the possession of some of the distinguishing marks of statehood": Lawrence. The Princtples of International Lau, supro n.15. at 73

Craig Owens quotes Heidegger's observation that the fact that the world be. comes a picture at all is "what distinguishes the essence of the modern age": Craig Owens. "The Discourse of Others: Feminists and Postmodernism", in H. Foster, ed.. The Antl-Aesthetic: Essays on Postmodern Culture (Seattle: Bay Press. 1983), 66. Note that whether this "transcendental perspective" represents an accu rate reflection of the philosophical position found in the canonical Enlightenment texts is not at issue here. What I describe is a popular or institutional view of the Enlightenment project from the vantage point of the nineteenth century international lawyer that. whether well-founded in the writings of Kant and others or not, provided the moral zeal for the international lawyer's task.

35 Cf. S. Toumlin. Cosmopolts: The Hidden Agendo of Modernity (Chicago: University of Chicago Press. 1990). 128. 
task is not simply to view the world in global or local terms but also to contribute to the architecture of this global space. The problem of enforcement of international law, for example, concerns the fact that violations of interna tional law take place simultaneously in local, domestic spheres, within the purview of another legal system. International lawyers must train citizens and governments who see only local events, therefore, to conceptualize them as events occurring also on an international plane. The lawyer's task becomes both to view the world in a way that makes possible a difference of dimension, and to maintain a boundary that delineates and defines the cosmopolitan space. The perspectives that animate the case are not simply different orders of seeing built together into one constant sense of scale, one way of reflecting on "place," therefore. Behind each fact or space is not just another fact but also another perspective. To change orders of knowledge is to change ways of seeing.

In this light, we can return to the legal arguments presented above as strategic shifts from one scale to another. The representation of a globalizing perspective, and the allusion to an international plane of activity, is as much a part of the American strategy, of course, as is the precise American argument about judicial procedure, for the American objective is to transform the conflict into a matter of diplomatic importance. Likewise, the British argument involves a shift of perspective that refuses the global. The shift to a different scale which is also a different order of knowledge - from law to fact. for example - entails an element of surprise. The appeal to the exoticism of the fact thus provides a means of refusing the international plane by suddenly dissipating the sense of physi cal closeness between American and British lawyers, and by moving to a different notion of what is close and what is far. The shift in perspective produces a confusion of categories - including literal miscegenation in the case of the British turn to citizenship arguments - which topples the possibility of conflict on a global scale. The perspectival trick here is to produce an element of the local which collapses the architecture of scale that differentiates local and global in the first place. The difference of scale between global and local gives the international plane its sense of "realness". When scale is collapsed, the difference between global and local is made to look unnatural, synthetic, two-dimensional rather than three.

In several recent works. Marilyn Strathern has described the scale that animates modern Euro-American knowledge. and the relationship of 


\section{Law and Critique Vol.VI no.1 [1995]}

scale to perspective, as an experience of partiality. In considering what it means for Euro-Americans to know things, Strathern relates notions of scale to an understanding of a diversity of ideas, facts, or forms. Dimension is created by the "constantly receding horizon of what there was to know ${ }^{36}$ such that every fact is grounded in other facts:

That modern dimension of grounding or context in turn yielded a sense of perspective, the "point of view" from which an entity was seen. One could always gain a new perspective by providing a new context for what was being observed ... This plurality was a given, and complex society awarded itself the ability to superimpose perspectives (self-conscious "constructions") upon a plurality inherent in the nature of things. ${ }^{3}$

At any level of scale, phenomena seem equally complex. Strathern argues. Switch from macro-analysis to micro-analysis, and the subject is no simpler. The resuit is a "relativizing effect," for our awareness that at another order of scale we would encounter new and equally complex set of phenomena "gives the observer a sense that any one approach is only ever partial, that phenomena could be infinitely multiplied." We experience "information loss" as we switch from one order of magnitude to another, and this creates the sense for us that our accounts are never sufficient. ${ }^{39}$ "An answer is another question, a connection a gap, a similarity a difference, and vice versa."

Yet in Strathem's account of modern knowledge, while perspectives change, scale itself is held constant. The difference between macro-analy sis and micro-analysis, for example, is not at issue for those EuroAmericans she describes, no matter how partial each level is understood to be. What are we to make, therefore, of the quintessentially liberal in ternational lawyers strategic movement between levels of scale that itself sometimes collapses scale and sometimes reconstructs it again? It perhaps is tempting to understand it as a kind of internal critique of the universalizing project of law and colonialism in which the coherence of global perspective is foiled by inner contradiction or the encroachment of

36 M. Strathern, After Nature: English Kinship in the Late Tuentieth Century (Cambridge: Cambridge University Press. 1992). 7.

37 Ibud at 8 (emphasis in original)

38 M. Strathern. Partual Connections (Savage, MD. Rowman \& Littlefield, 1991), xw:

39 Sbed at $x$ :

40 Ibud at xurv 
"difference".41 Yet to do so, I think, would be to fail to consider how the experience of what we interpret as powerful tools of critique were medi. ated for the nineteenth century Euro-American. In a study of distance, scale, and space in late nineteenth and early twentieth century Europe and America, for example, Stephen Kern finds that this period was marked precisely by a heterogeneity of perspective. ${ }^{2}$ Contrary to the "schizophrenia" which many postmodern theorists now read into notions of mutation or heterogeneity of perspective, ${ }^{43}$ Kern paints a picture of the apprehension of the irreconcilable partiality of perspectives as a source of creativity, innovation, and hope. ${ }^{4}$ In international legal conversation as well, we might conclude, strategic invocation of different orders of seeing, the distortion of scale, and the transformation of the subject from one scale to another, was a routine and comfortable part of the practice of international law, and one that gave effect to the very notion of scale it flattened.

One implication of this collapse of scale at the heart of modern liberalism's institutional project surely is to point out that much more is shared on a symbolic level between institutional elaborations of modernity on the

41 Following Foucault. for example. Paul Rabinow argues that the administrative discourses he documents in French Modern coalesce only momentarily before they dissolve into contradiction. See Rabinow, supra n.3.

42 From Albert Einstern's theory of relativity to Mauss and Durkheim's relativization of systems of classification and Nietzche's "perspectivism", the intel lectual climate was replete with the notion that space and distance was a mat. ter of perspective, that no inherent spatial reality existed outside of the many heterogeneous perspectives of the viewer: Stephen Kern. The Culture of Time and Space. 1880.1918 (Cambridge, Mass.: Harvard University Press, 1983. 132-138. Kern follows the trend into the arts. where he notes the innovations of painters such as Cézanne in introducing "truly heterogeneous space in a single canvas with multuple perspectives of the same subject," ibid. at 141 . and the cinema. where directors experimented with camera angles juxtaposed in rapid succession in a way that violated the singular transcendental perspective of past cinematography.

43 See, e.g., J. Baudrillard. America, trans. C. Turner (London: Verso, 1988); F. Jameson, Signatures of the Visible (New York: Routledge, 1990).

44 Kern notes, for example, the film critic Remy de Gourmont s celebration of the possibilities to "tour the world" in a single film, and Hugo Munsterberg's observation that in cinema. "lelvents which are far distant from one another so that we could not be physically present at all of them at the same time are fusing in our field of vision, just as they are brought together in our own con. sciousness ... Our mind is split and can be here and there apparently in one mental act": Kern, supra n.42, at 219. 


\section{Law and Critique Vol.VI no.1 [1995]}

one hand and contemporary critiques of that project on the other than of ten is assumed. The normative debate between post-colonial legal scholars and their subjects is made possible. it seems, by the way in which perspective is held constant. Whatever else they may not agree upon. late nineteenth and late twentieth century international lawyers, colonial administrators and post-colonial critics alike generally understand a difference of scale to separate the local and the global. Whether we choose to "think globally, and act locally. ${ }^{n 5}$ to represent and elaborate a new global space. ${ }^{46}$ to protect the local against the encroachment of global relations, ${ }^{47}$ or to marvel at its strangeness, ${ }^{48}$ we share a notion of scale that makes a normative critique intelligible. Often, moreover, this opposition induces precisely the normative debate about the elaboration of a cosmopolitan space of communication in which particularism can be reorganized into a universal whole which graced the pages of the international legal document a century ago

This is important. I believe, because there is a trend in contemporary scholarship that finds critical bite in making the point that the representations of "hegemonic" institutions such as international law are "partial," in emphasizing what is small, or local (and these two are often equated in this scholarship), or in trumpeting the confusion of categories that is taken to "warp" perspective. Yet as we rush to dismantle the architecture that sustains this international plane, to critique the pretensions of the globalizing gaze and to expose its partiality and the political interests it serves, caution seems in order. A look at the international lawyer's view

45 I have in mind the popular slogan of the international environmental movement.

46 See. e.g. D. Kennedy, "Autumn Weekends: An Essay on Law and Everyday Life". in A Sarat and T.R Kearns, eds.. Lau and Evervday Life (Ann Arbor: University of Michigan. 1993), 191-235

47 See. e.g. C. Geertz. Local Knouledge (New York: Basıc Books. 1983).

48 Guattari. for example. celebrates the "paradox" of the global which evidences "a multiplication of anthropological approaches. a planetary intermixing of cultures. paradoxically accompanied by a rising tide of particularisms, racisms, and nationalisms . F Guattari. "Regimes. Pathways. Subjects". in J. Crary and S. Kwinter, eds., Incorporattons (New York: Zone. 1992), 16.

49 William Connolly, for example, begins with the normative problem of how to bridge subjectivity - how to take seriously the difference of the other - and surprisingly ends on the topic of "global politics". See W. Connolly. "Identity and Difference in Global Politics". in J. Der Darien and MJ. Shapiro, eds., Internattonal/Intertextual Relations (Lexington. Mass: D.C. Heath. 1989), 333. 
indicates that this dismantling of the architecture that sustains the universalizing gaze is as central to the perspectival effect that delineates global and local as were the technologies that emphasized the distance between spheres. In perspectival terms, tearing down the scaffolding is quite the same as putting it back together again. Both share the same sense of scale--and as I have argued, this sense of scale was by no means marginal to the enterprise.

Likewise, the collapse of scale implicit in the flattening of perspective has been taken as indicative of a postmodern moment, ${ }^{50}$ one outside and beyond a modern past. The post-structuralist strategy of "fishing"51 knowledge out of context into a new pastiche, too, recalls the issue-spotting of the international lawyer. And indeed, recent post-structuralist writings seem to echo this international legal project when they advocate the deconstruction of nationhood through a method of reading out of context in the service of a new global space, understood, again, in terms of an opposition of unity to difference. ${ }^{52}$ Even the overlay of topographical and perspectival ways of apprehending knowledge that characterized the world of the international lawyer now finds considerable currency. ${ }^{53}$

50 See Baudrillard. supro n.2, at 128

51 I borrow the term from Vincente Rafael's recent study of the translation of Christian idioms into Tagalog. Rafael notes that "Listening-as-fishing and re membering-as haunung both entail the appropriation of what comes before one self (in both temporal and spatial senses). They are ways, therefore, of localizing what is outside of one" Vincente L Rafael. Contracting Colonialism: Translation and Christian Conversion in Tagalog Society under Early Spanish Rule (Durham. NC: Duke University Press, 1992). 12.

52 See, e.g. H.K. Bhabha. "Introduction: Narrating the Nation", in Nation and Narration (London Routledge. 1990), 4-5 (describing a new global space as "this inter national dimension both within the margins of the nation-space and in the boundaries in hetueen nations and peoples... (and) the problematic unity of the nation to the articulation of cultural difference in the construction of an inter national per spective") (emphasis in originall.

53 I am thinking here of the affinity between theories that focus on categories and the boundaries that dehneate them, theories that map out networks of relationships, and theories that emphasize the relationship between perspectives on a subject in the domain of critical international law. for example. Ashley and Walker's study of sovereignty integrates a "suspicion of all assertions of sovereign privilege ... a vorce beyond politics and beyond doubt. a voice of in terpretation and judgment from which truth and power are thought to em. anate as one" with a critique of at tempts to delineate and defend disciplinary and territortal boundaries. See R. K. Ashley, and R.B.J. Walker. "Reading Dissidence/Writing the Discipline: Crisis and the Question of Sovereignty in 


\section{Law and Critique Vol.VI no.1 [1995]}

However, as we have seen, the distortion of perspective, the deconstruction of orders of knowledge and their recombination into new and unnatural vistas is as much a part of the effect of liberalism as it is a part of postmodern critique and imagination.

Finally, the alternation between incommensurable perspectives associated with contemporary feminist theory claims for itself a vantage point set apart from liberalism that provides a possibility for critique. Yet as we saw, the international lawyer's distance between global and local was effected in part by the occupation of seemingly incongruous positions. This realization demands, I think, that we question the power of perspectivism as a tool for imagining a new and truly postcolonial law or politics.

I do not intend these observations as yet another layer of critique, however. The realization that our contemporary perspectival moves against scale were anticipated a century ago is devastating only if one assumes that what productive academics do is critique, and that critique involves transforming or otherwise making something of perspective. Perspective, from this position, is always assumed to be perspective on something, something that itself is not a perspective but rather a kind of raw material for observation. The object or focal point of perspective, for the critic, is the fact upon which the scholar or lawyer works her theory.

Yet if we turn back to the international legal arguments above, we find that the global is both perspective and place. Perspective is also its own subject matter, and the act of viewing and the material that is viewed are one and the same. Behind perspective is not just the thing that is viewed (space) but also another perspective.

To take a cue from the scale of the international plane, in which the incommensurables of perspective and space were already one, therefore, we might turn our attention to this contemporary notion of perspective as an "outside" and therefore productive critical move. We can begin with

the recognition that a critique or view that comes "after" is always also the territory that comes before.

International Studies”, International. Studies Quarterly 34 (1990), 367. 